\title{
HIGHLIGHTS
}

IBD

\section{Visilizumab not useful for intravenous steroid-refractory ulcerative colitis}

The potential of T-cell based therapies for severe ulcerative colitis has been called into question by the findings of an international, multicenter study.

Two open-label trials had indicated that visilizumab-a monoclonal antibody to the T-cell receptor CD3-was efficacious for intravenous corticosteroid-refractory ulcerative colitis. William Sandborn and colleagues therefore conducted a 90-day randomized, double-blind, placebocontrolled trial of visilizumab in this patient population at a dose of $5 \mu \mathrm{g} / \mathrm{kg}$ administered on days 1 and 2 .

\section{4 ....visilizumab was not more effective than placebo for inducing response and remission... 77}

“The study demonstrated that visilizumab was not more effective than placebo for inducing response and remission, and for preventing colectomy in patients with intravenous corticosteroidrefractory ulcerative colitis," explains Sandborn, corresponding author of the study. Including a placebo group showed that steroid therapy and/or the patients' natural history accounted for the observed results, rather than visilizumab. Infections, cytokine release syndrome, cardiac disorders and vascular disorders were also more common in the visilizumab group.

"The complete lack of efficacy despite near-complete T-cell depletion suggests that other treatment strategies that block or deplete T cells in patients with ulcerative colitis may not be effective," concludes Sandborn.

Natalie J. Wood

Original article Sandborn, W. J. et al. Anti-CD3 antibody visilizumab is not effective in patients with intravenous corticosteroid-refractory ulcerative colitis. Gut 59 , 1485-1492 (2010) 